\title{
Association of the TP53 Arg72Pro Polymorphism with Oral Squamous Cell Carcinoma: A Meta-Analysis
}

\author{
SARR PD ${ }^{1,2}$, BA SA ${ }^{2}$, TOURE $S^{3}$, DIOP JPD ${ }^{1,2}$, DIA $Y^{1,2}$, MBENGUE ${ }^{2}$, SYLLA NIANG ${ }^{2}$, FAYE $0^{1}$, DIEYE $A^{2}$ and NDIAYE \\ DIALLO R $\mathbf{R}^{1,2}$
}

${ }^{1}$ Laboratory of Clinical Cytology, Cytogenetics and Biology of Reproduction, Aristide Le Dantec Hospital, Dakar, Senegal ${ }^{2}$ Immunogenetic Laboratory, Faculty of Medicine, Pharmacy and Odontology, Cheikh Anta Diop University, Dakar, Senegal ${ }^{3}$ Stomatology Department, Aristide Le Dantec Hospital, Dakar, Senegal

\begin{abstract}
Background: The loss of function in TP53 gene is an early event of carcinogenesis and is now considered as a full etiological factor in oral squamous cell carcinoma (OSCC). The most common polymorphism in this gene that is associated to OSCC and has been extensively studied as a potential risk factor for the development of malignancies is the single nucleotide polymorphism (SNP) encoding either proline or arginine at residue 72. Today, despite the multiplicity of publications and approaches used, the contradiction of the results have not remove the ambiguity of the possible impact of this polymorphism in OSCC. So we aimed this meta-analysis to investigate the distribution of TP53 codon 72 genotypes and alleles in patients with OSCC and healthy matched controls, by using an ethnicity subgroups analysis.
\end{abstract}

Method: A literature search was conducted to identify studies concerning TP53 codon 72 polymorphism and OSCC risk. Retrieved publications from 2000 to 2014 were classified by ethnicity, according to the sampling collection continent. Allelic frequencies were estimated by using genotypic data and Hardy-Weinberg Equilibrium and distributions were checked with Chi-2 test. Statistical tests for contrast models of association were performed with Proline allele as reference stratum.

Results: Arg allele distribution was almost similar in both cases and controls for African and Caucasian populations whereas Arg frequency was significantly greater in cases than in controls for Asians $(p=0.011)$. After stratified statistical analyses, we've found again a significant association between Arginine allele and OSCC risk in the Asian subgroup (OR=1.31; 95\% $\mathrm{Cl}=1.09-1.58 ; P=0.004$ ).

Conclusion: This current study revealed that allelic distribution of TP53 Arg72Pro polymorphism may depend on ethnicity and latitude, and highlighted that Arginine carrier in Asian populations may be considered to be predisposed to OSCC.

Keywords: TP53 • Arg72Pro polymorphism • OSSC $・$ Meta-analysis

Abbreviations: Cl: Confidence Interval • HPV: Human Papilloma Virus • HWE: Hardy-Weinberg Equilibrium • OR: Odds-Ratio • OSCC: Oral Squamous Cell Carcinoma $\cdot$ SNP: Single Nucleotide Polymorphism

\section{Introduction}

Oral squamous cell carcinoma (OSCC) are multifactor tumors mainly correlated with tobacco smoke, alcohol abuse, betel nut chewing, high-risk human papillomavirus (HPV) infection and molecular alterations of genes involved in cell cycle regulation like TP53 [1]. The inactivation or degradation of TP53, the main "guardian of the genome", is now considered as a full etiological factor in carcinogenesis and the main event that precedes most cancers [2]. This gene is a tumor suppressor gene and is the most frequently mutated in human cancers. More than $50 \%$ of cancers in humans express a mutation in this gene [3-5]. The encoded protein mediates in the prevention of neoplastic transformation by repairing DNA damages after replication, or by inducing apoptosis in case DNA damages couldn't be repaired [6].

In cancerous tissues, particularly in oral squamous cells, the loss of function at TP53 is generally associated with three molecular causes: the genotoxic effect of risk factors such as alcohol, tobacco, betel nut, the inhibitory

*Address for Correspondence: Dr. Ndiaye-Diallo Rokhaya, Laboratory of Clinical Cytology, Cytogenetics and Biology of Reproduction, Aristide Le Dantec Hospital, Dakar, Senegal, E-mail: rokhaya9.ndiaye@ucad.edu.sn

Copyright: (c) 2020 Sarr PD, et al. This is an open-access article distributed under the terms of the Creative Commons Attribution License, which permits unrestricted use, distribution, and reproduction in any medium, provided the original author and source are credited.

Received 08 July 2020; Accepted 21 July 2020; Published 28 July 2020 effect of the TP53 antagonist gene MDM2 or the oncotic action of E6-HPV [7-9]. Now-a-days, the study of the TP53 gene signaling pathways, as well as the control of its protein stability or expression constitutes the new approaches to anticancer research $[10,11]$.

TP53 is a sequence-specific DNA-binding transcription factor comprising four domains: a highly charged acidic region (transactivation domain), a hydrophobic proline-rich region (protein interaction domain), a central region (DNA binding domain), and a highly basic $\mathrm{COOH}$-terminal region (oligomerization domain) [12].

The most common TP53 polymorphism that is associated to OSCC and has been extensively studied as a potential risk factor for the development of malignancies is the single nucleotide polymorphism (SNP) encoding either proline or arginine at residue 72 within the proline-rich domain $[4,5,8,13]$. This non-conservative amino acid change is associated with altered electrophoretic mobility in the mutant protein that contain Arg72 allele, thus suggesting a structural or conformational modification of the TP53 protein [12].

Several reports have described differences in functional properties of wild-type TP53, including susceptibility to malignant transformation, ubiquitinmediated degradation by high-risk HPV E6-protein, induction of apoptosis or cell cycle progression after damage $[1,9,12,14,15]$.

The possible impact of TP53 codon 72 genotypes on malignancies development yet remains an ongoing issue of debate because of contradictory results of statistical and in silico analysis. Hou and colleagues in 2015 tried to illustrate these contradictory results through the picture bellow, showing different trends and weights of association between Arg72 allele of TP53 
protein and OSCC risk through 12 studies [16] (Figure 1). These contradictory results could be explained by the different geographic distribution of genotypic frequency of TP53 codon 72 polymorphism. The allelic frequency is said to be depend on ethnicity and geographic latitude [17-21].

For this purpose, the aim of this meta-analysis was to investigate the distribution of TP53 codon 72 genotypes and alleles in patients with OSCC and healthy matched controls, and study the impact of this amino-acid variability on the risk of developing OSCC, by using ethnicity subgroups analysis.

\section{Research Methodology}

\section{Publications selection process}

Were included in this meta-analysis all case-control studies published before December 2018, concerning TP53 Arg72Pro polymorphism and OSCC, with detailed genotypic frequencies in the cases and controls. We excluded all review articles, meta-analysis and case-only studies.

We carried out a comprehensive search in PubMed and Science Direct databases with the following keywords: "TP53 codon 72" - "Arg72Pro polymorphism" - "oral cancer" - "oral squamous cell carcinoma". All eligible studies were retrieved, and their references were checked for additional relevant publications.

\section{Quality assessment}

The quality of the included studies was assessed according to the concordance of Hardy-Weinberg equilibrium (HWE) for the genotypic distribution in controls, to detect possible selection bias $[16,22,23]$. Studies with genotypic distribution of controls in concordance with HWE $(P>0.05)$ were defined as high-quality studies, while studies inconsistent with HWE $(P \leq 0.05)$ were classified as low-quality studies.
A symetry Begg's funnel plot that allows detecting potential publication bias in a meta-analytic study was also performed to assess the quality of publications. Publications in the inefficiency zone, which deviate from confidence funnel-shaped interval, are therefore suspected to be biased [24-30].

\section{Statistical analysis}

Allelic frequencies were estimated by using genotyping data extracted from selected publications and HWE formula. Stratified analysis was performed according to three ethnic groups and geographical latitude: Africans corresponding to black-skinned Sahelian and Sub-Saharan, Asians are populations living in East, Southeast and Central Asia and Caucasians are white European and white non-hispanic American.

We first check the distribution of Arginine and Proline alleles in ethnic subgroups by using Chi-2 test. STATA version 12.0 software (Stata Corporation, College Station, TX) was used for this statistical comparison.

Statistical tests for contrast models of association were performed with Proline allele as reference stratum. The strength of the association was estimated through an online dedicated website by the pooled odds ratio (OR) with its corresponding 95\% confidence interval $(95 \% \mathrm{Cl})$ and $P$-value [24] The pooled ORs were calculated for following contrasts models, using Proline allele as reference stratum : Arg/Arg vs. Pro/Pro, Arg/Arg vs. Arg/Pro, Arg/Pro vs. Pro/Pro, Arg/Arg + Arg/Pro vs. Pro/Pro, Arg/Arg vs. Arg/Pro + Pro/Pro and Allele Arg vs. Allele Pro.

\section{Results}

\section{Studies characteristics}

A total of 16 studies met the inclusion criteria (Figure 2). Publications characteristics are summarized in Table 1 . Overall number of participants was

$$
\text { Study }
$$

OR $(95 \% \mathrm{Cl})$

$\%$

Weight

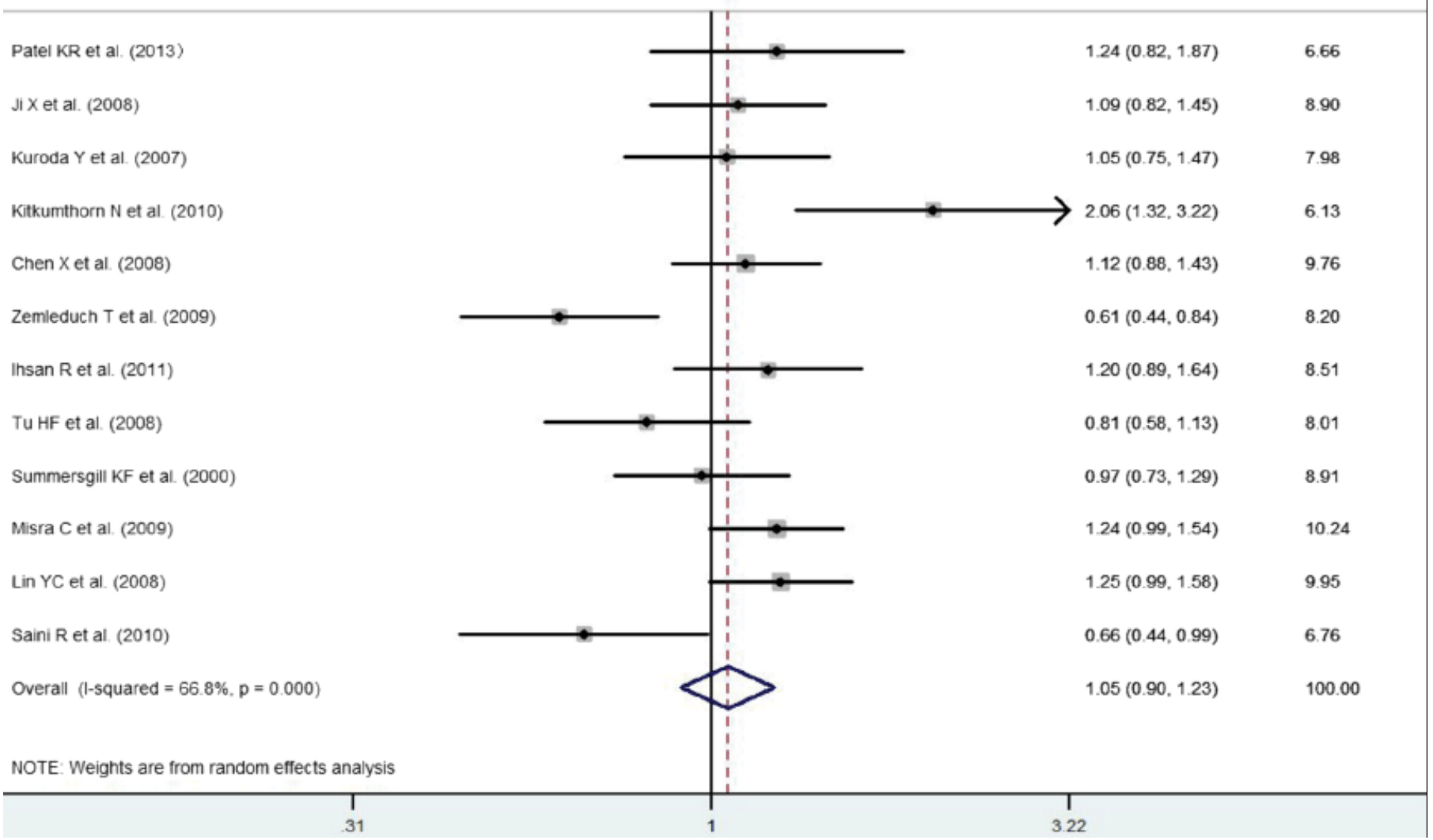

Figure 1. The contradictory results of association between Arg72 allele and OSCC risk in 12 studies throughout the world [16]. 


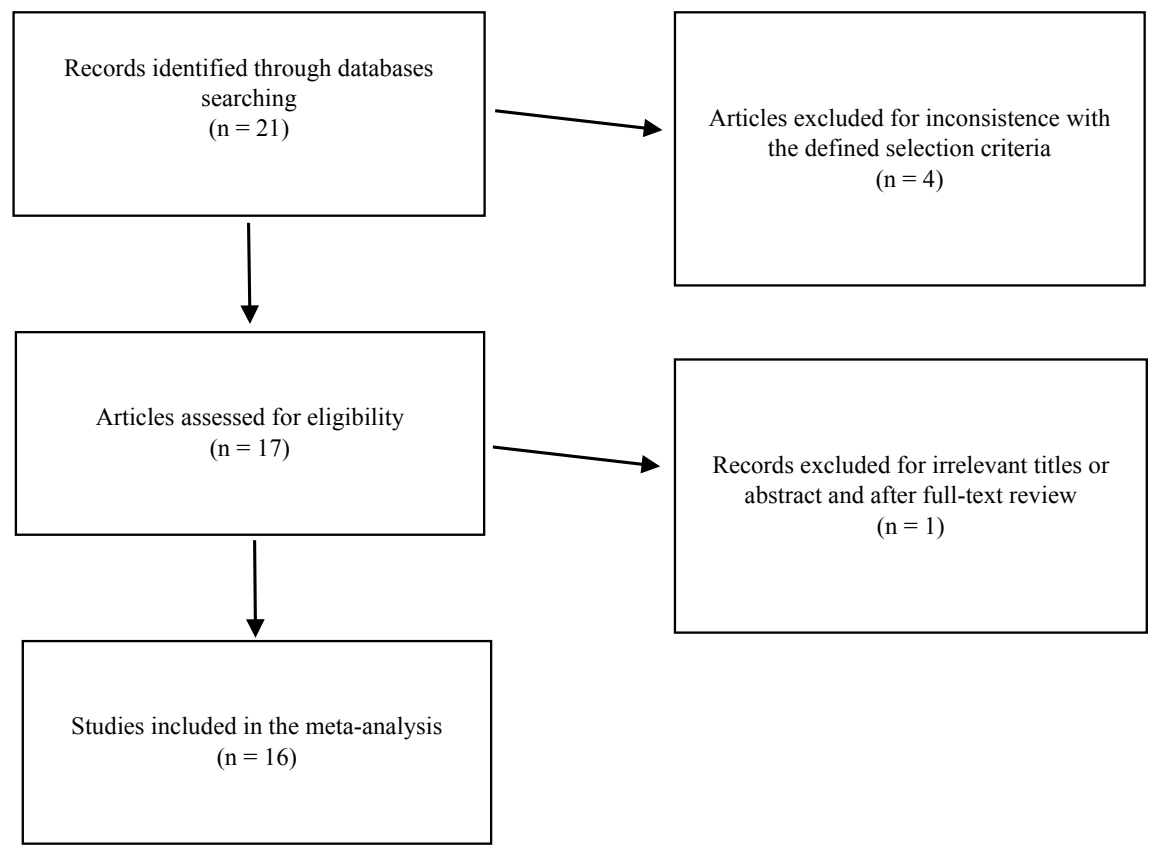

Figure 2. Flow chart of the publication selection process.

Table 1. Characteristics of 16 studies included in this meta-analysis.

\begin{tabular}{|c|c|c|c|c|c|}
\hline First author [Reference] & Country & $\begin{array}{c}\text { Year of } \\
\text { publication }\end{array}$ & Ethnicity & Genotyping Methods & $\begin{array}{l}\text { Samples Size (case/ } \\
\text { control) }\end{array}$ \\
\hline $\mathrm{Ba} S \mathrm{~A}[25]$ & Senegal & 2014 & African & PCR-RFLP & $51 / 87$ \\
\hline Chen X [15] & Texas, USA & 2008 & Caucasian & PCR-RFLP & $326 / 349$ \\
\hline Hamel N [26] & Montreal, Canada & 2000 & Caucasian & PCR-RFLP & $163 / 163$ \\
\hline $\mathrm{JiX}[9]$ & Texas, USA & 2008 & Caucasian & PCR-RFLP & 188/342 \\
\hline Kietthubthew S [7] & Southern Thailand & 2003 & Asian & PCR-RFLP & $97 / 97$ \\
\hline Lin Y C [27] & Taiwan & 2008 & Asian & PCR-RFLP & $297 / 280$ \\
\hline Lu J [28] & Texas, USA & 2007 & Caucasian & PCR-RFLP & $716 / 719$ \\
\hline Mojtahedi Z [3] & Iran & 2010 & Asian & PCR-SSP & $132 / 123$ \\
\hline Perrone F [1] & Italia & 2007 & Caucasian & Two-step PCR & $77 / 141$ \\
\hline Scheckenbach K [12] & Germany & 2004 & Caucasian & RT-PCR ; Direct sequencing & $122 / 193$ \\
\hline Shen H [4] & Texas, USA & 2002 & Caucasian & PCR-RFLP & $304 / 333$ \\
\hline Sina M [29] & Iran & 2014 & Asian & ARMS-PCR (Alleles spec.) & $55 / 100$ \\
\hline Tu H F [30] & Taiwan & 2008 & Asian & Direct sequencing & 189/116 \\
\hline Twu C w [13] & Taiwan & 2006 & Asian & PCR-RFLP & $53 / 53$ \\
\hline Yang W [5] & China & 2008 & Asian & Direct sequencing & $435 / 550$ \\
\hline Yu H [8] & Texas, USA & 2011 & Caucasian & PCR-RFLP & $1083 / 1090$ \\
\hline Overall : & & & 9024 participants & & $4288 / 4736$ \\
\hline
\end{tabular}

Note: PCR: Polymerase Chain Reaction, ARMS-PCR: Amplification Refractory Mutation System PCR, PCR-RFLP: PCR-Restriction Fragment Length Polymorphism, PCR-SSP: PCR-Sequence Specific Primers, RT-PCR: Reverse Transcriptase PCR.

9024 including 4288 cases and 4736 controls.

\section{Quality assessment}

Data extracted from included studies and their quality assessment according to HWE test in controls is presented in Table 2. Two publications with genotype distribution in controls departing from HWE were classified as low quality studies while the other fourteen publications in agreement with HWE were defined as high-quality studies [1,3-5,7-9,12,13,15,25-30].

The symmetrical Begg's funnel plot showed two publications in the zone of inefficiency that we then suspected to be biased (Figure 3) $[5,13]$.

\section{Meta-analysis}

Allelic distribution: We have first classified studies in three ethnic subgroups according to the samplings continents: 1 publication with 51 cases and 87 controls was African, 7 articles with 1258 cases and 1319 controls were Asians and 8 articles with 2979 cases and 3330 controls were Caucasians

\section{$[1,3-5,7-9,12,13,15,25-30]$.}

The allelic distributions presented in Table 2 showed that in Africa and in Caucasians, the Arginine allele distribution is almost similar in both cases and controls (Africa: $29.4 \%$ in cases, $32.8 \%$ in controls; Caucasians: $73.5 \%$ in cases, $73.3 \%$ in controls) while a clear difference was noticed in Asia $(67.9 \%$ in cases, $61.9 \%$ in controls). Comparison by khi-2 test of Arg allelic frequencies between cases and controls in Table 3 was statistically significant in Asian subgroups $(P=0.011)$. We then concluded that Arginine allele of codon 72 of TP53 may be a risk factor for OSCC in Asian population.

Contrast models analysis in subgroups: In order to validate the hypothesis aforementioned in allelic distribution and check out the effect of Arginine allele in the different ethnic groups, we tested three statistical parameters (Odds ratio, $\mathrm{p}$-value and $95 \% \mathrm{Cl}$ ) in contrast models of association, by using the proline allele as a reference stratum (Table 4).

We found in Asian subgroup significant associations between the 
Table 2. Distribution of TP53 codon 72 genotypes and alleles among cases and controls in the studies included in this meta-analysis and quality assessment of their controls according to HWE test.

\begin{tabular}{|c|c|c|c|c|c|c|c|c|c|c|c|}
\hline \multirow[b]{2}{*}{$\begin{array}{l}\text { First author } \\
\text { [Reference] }\end{array}$} & \multirow[b]{2}{*}{$\begin{array}{l}\text { Sample size } \\
\text { (case/control) }\end{array}$} & \multicolumn{4}{|c|}{ Genotype \& allelic frequencies in cases } & \multicolumn{4}{|c|}{ Genotype \& allelic frequencies in controls } & \multirow[b]{2}{*}{$\begin{array}{l}P \text {-value } \\
\text { of HWE in } \\
\text { controls }\end{array}$} & \multirow[b]{2}{*}{ HWE test in controls } \\
\hline & & $\begin{array}{l}\text { Arg/Arg } \\
\%-(n)\end{array}$ & $\begin{array}{c}\text { Arg/Pro } \\
\%-(n)\end{array}$ & $\begin{array}{l}\text { Pro/Pro } \\
\%-(n)\end{array}$ & $\begin{array}{c}\text { Alleles } \\
\text { Arg/ Pro } \\
(\%)\end{array}$ & $\begin{array}{l}\text { Arg/Arg } \\
\%-(n)\end{array}$ & $\begin{array}{l}\text { Arg/Pro } \\
\%-(n)\end{array}$ & $\begin{array}{l}\text { Pro/Pro } \\
\%-(n)\end{array}$ & $\begin{array}{c}\text { Alleles } \\
\text { Arg/ Pro } \\
(\%)\end{array}$ & & \\
\hline $\mathrm{Ba} \mathrm{SA}[25]$ & $51 / 87$ & $6 \%(3)$ & $47 \%(24)$ & $47 \%(24)$ & $29,4 / 70,6$ & $14 \%(12)$ & $38 \%(33)$ & $48 \%(42)$ & $32,8 / 67,2$ & 0,159 & High quality \\
\hline Chen X [15] & $326 / 349$ & $\begin{array}{c}56,1 \% \\
(183) \\
\end{array}$ & $\begin{array}{c}37,1 \% \\
(121) \\
\end{array}$ & $6,8 \%(22)$ & $74,6 / 25,4$ & $\begin{array}{c}51,9 \% \\
(181) \\
\end{array}$ & $\begin{array}{c}41,2 \% \\
(144) \\
\end{array}$ & $6,9 \%(24)$ & $72,5 / 27,5$ & 0,740 & High quality \\
\hline Hamel N [26] & $163 / 163$ & $\begin{array}{c}54,0 \% \\
(88)\end{array}$ & $\begin{array}{c}41,7 \% \\
(68) \\
\end{array}$ & $4,3 \%(7)$ & $74,8 / 25,2$ & $\begin{array}{c}58,3 \% \\
(95) \\
\end{array}$ & $\begin{array}{c}37,4 \% \\
(61) \\
\end{array}$ & $4,3 \%(7)$ & $77,0 / 33,0$ & 0,576 & High quality \\
\hline Ji X [9] & $188 / 342$ & $\begin{array}{c}54,8 \% \\
(103) \\
\end{array}$ & $\begin{array}{c}39,4 \% \\
(74) \\
\end{array}$ & $5,8 \%$ (11) & $74,5 / 25,5$ & $\begin{array}{l}52,4 \% \\
(179) \\
\end{array}$ & $\begin{array}{l}40,9 \% \\
(140) \\
\end{array}$ & $6,7 \%(23)$ & $72,8 / 27,2$ & 0,734 & High quality \\
\hline Kietthubthew S [7] & $97 / 97$ & $33 \%(32)$ & $45 \%(44)$ & $22 \%(21)$ & $55,5 / 44,5$ & 36 \% (35) & $35 \%$ (34) & $29 \%$ (28) & $53,5 / 46,5$ & 0,003 & Low quality $^{* * *}$ \\
\hline Lin Y C [27] & $297 / 280$ & $\begin{array}{c}33,2 \% \\
(96) \\
\end{array}$ & $\begin{array}{c}52,2 \% \\
(155) \\
\end{array}$ & $\begin{array}{c}15,5 \% \\
(46) \\
\end{array}$ & $59,3 / 40,7$ & $\begin{array}{c}25,7 \% \\
(72) \\
\end{array}$ & $\begin{array}{c}54,3 \% \\
(152) \\
\end{array}$ & $\begin{array}{c}20,0 \% \\
(56) \\
\end{array}$ & $52,8 / 47,2$ & 0,370 & High quality \\
\hline Lu J [28] & $716 / 719$ & $\begin{array}{l}55,9 \% \\
(400) \\
\end{array}$ & $\begin{array}{c}37,7 \% \\
(270) \\
\end{array}$ & $6,4 \%(46)$ & $74,7 / 25,3$ & $\begin{array}{l}54,0 \% \\
(388) \\
\end{array}$ & $\begin{array}{c}40,2 \% \\
(289) \\
\end{array}$ & $5,8 \%(42)$ & $74,1 / 25,9$ & 0,636 & High quality \\
\hline Mojtahedi Z [3] & $132 / 123$ & $\begin{array}{c}37,1 \% \\
(49) \\
\end{array}$ & $\begin{array}{c}47,7 \% \\
(63) \\
\end{array}$ & $\begin{array}{c}15,2 \% \\
(20) \\
\end{array}$ & $55,5 / 44,5$ & $\begin{array}{c}35,8 \% \\
(44) \\
\end{array}$ & $\begin{array}{c}51,2 \% \\
(63) \\
\end{array}$ & $\begin{array}{c}13,0 \% \\
(16) \\
\end{array}$ & $61,4 / 38,6$ & 0,422 & High quality \\
\hline Perrone F [1] & $77 / 141$ & $\begin{array}{c}81,8 \% \\
(63) \\
\end{array}$ & $10,4 \%(8)$ & 7,8 \% (6) & $87,0 / 13,0$ & $\begin{array}{c}59,6 \% \\
(84) \\
\end{array}$ & $\begin{array}{c}33,3 \% \\
(47) \\
\end{array}$ & $7,1 \%(10)$ & $76,2 / 23,8$ & 0,420 & High quality \\
\hline $\begin{array}{c}\text { Scheckenbach } \\
\text { K [12] }\end{array}$ & $122 / 193$ & $54 \%(66)$ & $1 \%(1)$ & $45 \%(55)$ & $54,5 / 45,5$ & 59 \% (114) & 7 \% (13) & $34 \%(66)$ & $62,5 / 37,5$ & 0,000 & Low quality*** \\
\hline Shen H [4] & $304 / 333$ & $\begin{array}{c}52,0 \% \\
(158) \\
\end{array}$ & $\begin{array}{c}41,1 \% \\
(125) \\
\end{array}$ & $6,9 \%(21)$ & $72,5 / 27,5$ & $\begin{array}{c}52,6 \% \\
(175) \\
\end{array}$ & $\begin{array}{l}40,2 \% \\
(134) \\
\end{array}$ & $7,2 \%(24)$ & $72,7 / 27,3$ & 0,898 & High quality \\
\hline Sina M [29] & $55 / 100$ & $\begin{array}{c}36,4 \% \\
(20) \\
\end{array}$ & $\begin{array}{c}45,5 \% \\
(25) \\
\end{array}$ & $\begin{array}{c}18,2 \% \\
(10) \\
\end{array}$ & $59,1 / 40,9$ & $\begin{array}{c}40,0 \% \\
(40) \\
\end{array}$ & $\begin{array}{c}48,0 \% \\
(48) \\
\end{array}$ & $\begin{array}{c}12,0 \% \\
(12) \\
\end{array}$ & $64,0 / 36,0$ & 0,676 & High quality \\
\hline Tu H F[30] & $189 / 116$ & $\begin{array}{c}28,0 \% \\
(53) \\
\end{array}$ & $\begin{array}{c}56,1 \% \\
(106) \\
\end{array}$ & $\begin{array}{c}15,9 \% \\
(30)\end{array}$ & $56,1 / 43,9$ & $\begin{array}{c}35,3 \% \\
(41) \\
\end{array}$ & $\begin{array}{c}51,7 \% \\
(60) \\
\end{array}$ & $\begin{array}{c}13,0 \% \\
(15) \\
\end{array}$ & $61,1 / 38,9$ & 0,378 & High quality \\
\hline Twu C W [13] & $53 / 53$ & $\begin{array}{c}22,6 \% \\
(12) \\
\end{array}$ & $\begin{array}{c}51,0 \% \\
(27) \\
\end{array}$ & $\begin{array}{c}26,4 \% \\
(14) \\
\end{array}$ & $48,1 / 51,9$ & $\begin{array}{c}41,5 \% \\
(22) \\
\end{array}$ & $\begin{array}{c}45,3 \% \\
(24) \\
\end{array}$ & $13,2 \%(7)$ & $64,1 / 35,9$ & 0,879 & High quality \\
\hline Yang W [5] & $435 / 550$ & $\begin{array}{c}85,7 \% \\
(373) \\
\end{array}$ & $4,4 \%(19)$ & $9,9 \%(43)$ & $87,9 / 12,1$ & $\begin{array}{c}49,6 \% \\
(273) \\
\end{array}$ & $\begin{array}{c}35,8 \% \\
(197) \\
\end{array}$ & $\begin{array}{c}14,6 \% \\
(80) \\
\end{array}$ & $67,5 / 32,5$ & 0,065 & High quality \\
\hline Yu H [8] & $1083 / 1090$ & $\begin{array}{c}54,8 \% \\
(593) \\
\end{array}$ & $\begin{array}{c}37,4 \% \\
(405) \\
\end{array}$ & $7,8 \%$ (85) & $73,5 / 26,5$ & $\begin{array}{c}54,8 \% \\
(597) \\
\end{array}$ & $\begin{array}{c}39,3 \% \\
(428) \\
\end{array}$ & $5,9 \%(65)$ & $74,4 / 25,6$ & 0,741 & High quality \\
\hline Overall & $4288 / 4736$ & $\begin{array}{l}53,4 \% \\
(2292) \\
\end{array}$ & $\begin{array}{l}35,8 \% \\
(1535) \\
\end{array}$ & $\begin{array}{c}10,8 \% \\
(461) \\
\end{array}$ & $71,3 / 28,7$ & $\begin{array}{l}49,7 \% \\
(2352) \\
\end{array}$ & $\begin{array}{l}39,4 \% \\
(1867) \\
\end{array}$ & $\begin{array}{c}10,9 \% \\
(517)\end{array}$ & $69,4 / 30,6$ & 0,469 & High quality \\
\hline \multicolumn{12}{|c|}{ Stratified by ethnicity } \\
\hline African & $51 / 87$ & $6 \%(3)$ & $47 \%(24)$ & $47 \%(24)$ & $29,4 / 70,6$ & $14 \%(12)$ & $38 \%(33)$ & $48 \%(42)$ & $32,8 / 67,2$ & 0,159 & High quality \\
\hline Asian & $1258 / 1319$ & $\begin{array}{c}50,5 \% \\
(635) \\
\end{array}$ & $\begin{array}{c}34,9 \% \\
(439) \\
\end{array}$ & $\begin{array}{c}14,6 \% \\
(184) \\
\end{array}$ & $67,9 / 32,1$ & $40 \%(527)$ & $\begin{array}{c}43,8 \% \\
(578) \\
\end{array}$ & $\begin{array}{c}16,2 \% \\
(214) \\
\end{array}$ & $61,9 / 38,1$ & 0,475 & High quality \\
\hline Caucasian & $2979 / 3330$ & $\begin{array}{l}55,5 \% \\
(1654)\end{array}$ & $\begin{array}{c}36 \% \\
(1072)\end{array}$ & $\begin{array}{l}8,5 \% \\
(253)\end{array}$ & $73,5 / 26,5$ & $\begin{array}{l}54,5 \% \\
(1813)\end{array}$ & $\begin{array}{l}37,7 \% \\
(1256)\end{array}$ & $\begin{array}{l}7,8 \% \\
(261)\end{array}$ & $73,3 / 26,7$ & 0,721 & High quality \\
\hline
\end{tabular}

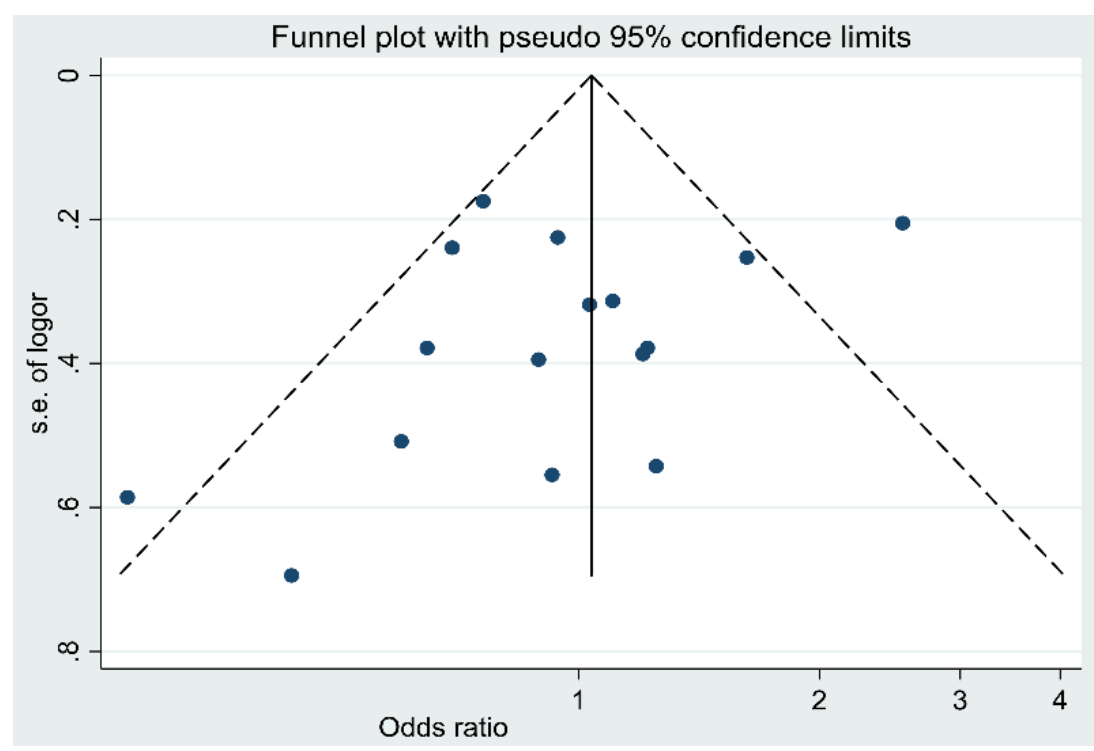

Figure 3. Begg's funnel plot analysis to detect publication bias with pseudo $95 \%$ confidence limits. Each point represents an individual study for the indicated association; the $x$-axis shows the results of studies expressed as odds-ratio; the y-axis shows the studies precisions; the middle solid line indicates the overall effect from the meta-analysis. 
Table 3. Arginine allele distribution \& Khi-2 test comparison between cases and controls in ethnic subgroups.

\begin{tabular}{ccc}
\hline \multirow{2}{*}{ Ethnicity } & \multicolumn{2}{c}{ Arg allele cases vs controls } \\
\cline { 2 - 4 } & Arg allele frequencies & z-value \\
\hline African & $29.4 \% / 32.8 \%$ & 0.817 \\
\hline Asian & $67.9 \% / 61.9$ & 6.441 \\
\hline Caucasian & $73.5 \% / 73.3$ & 0.366 \\
\hline
\end{tabular}

Table 4. Meta-analysis of the associations between TP53 codon 72 polymorphism and OSCC risk - Ethnicity subgroups analysis.

Contrast models

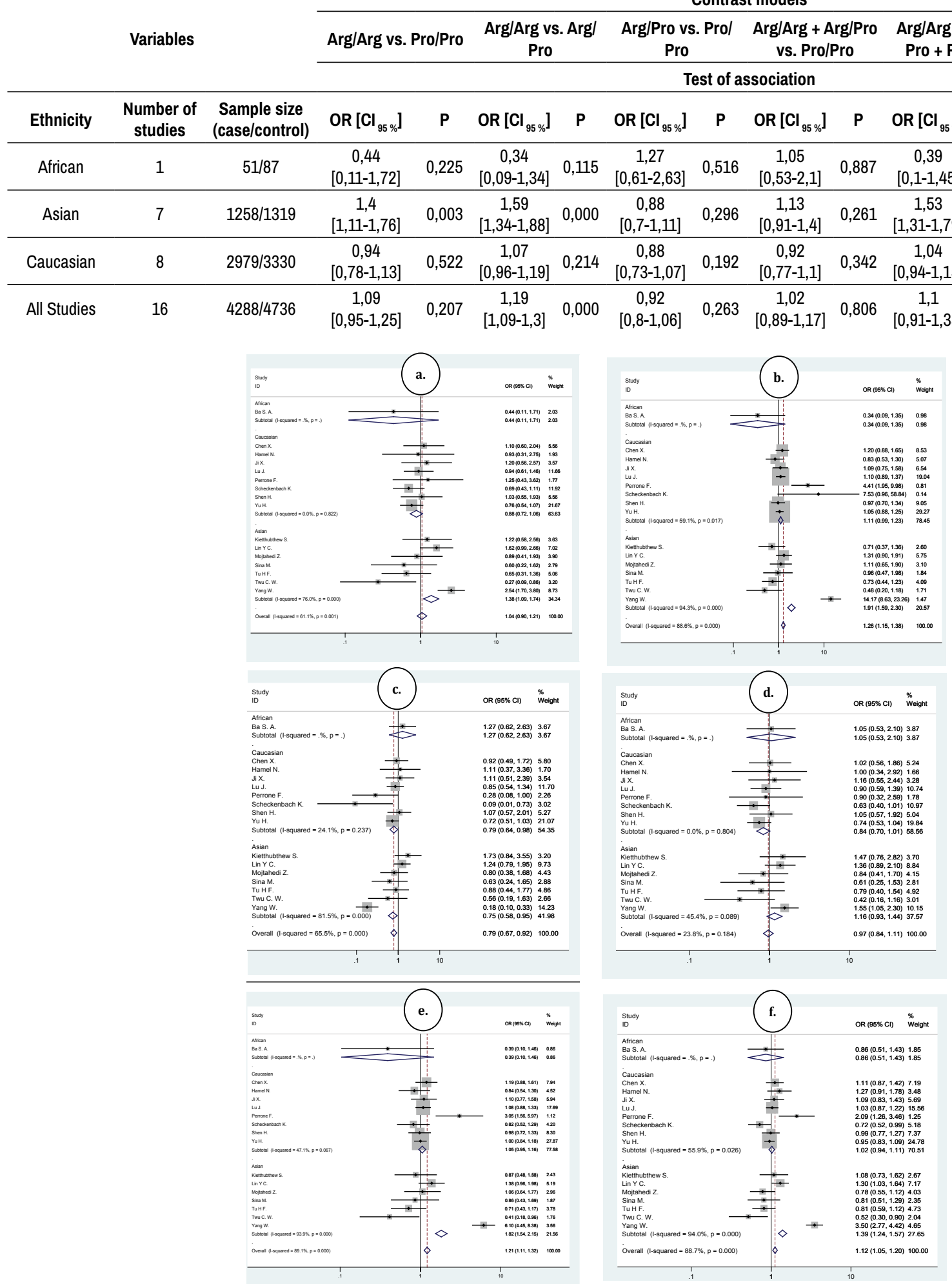

Figure 4. Forest plots of OSCC risk associated with the TP53 Arg72Pro polymorphism in all included studies, stratified by ethnicity. Boxes represent the ORs of individual studies; diamonds represent the summary ORs; horizontal lines represent the 95\% Cls. a. Arg/Arg vs. Pro/Pro. b. Arg/Arg vs. Arg/Pro. c. Arg/Pro vs. Pro/Pro. d. Arg/Arg + Arg/Pro vs. Pro/Pro. e. Arg/Arg vs. Arg/Pro + Pro/Pro. f. Allele Arg vs. Allele Pro. 
TP53 Arg72Pro polymorphism and OSCC risk for 4 contrasts models : Arg/ Arg vs. Pro/Pro [OR=1.4; 95\% Cl=1.11-1.76; $P=0.003] ; \quad$ Arg/Arg vs. Arg/ Pro [OR=1.59; $95 \% \mathrm{Cl}=1.34-1.88 ; \quad P=0.000] ;$ Arg/Arg vs. Arg/Pro + Pro/ Pro [OR=1.53; 95\% $\mathrm{Cl}=1.31-1.79 ; \quad P=0.000]$ and Allele Arg vs. Allele Pro [OR=1.31; 95\% Cl=1.09-1.58; $P=0.004$ ].

Forest plots based on contrast models that we have tested were drawn to have an overall watch on meta-analysis results (Figure 4).

\section{Discussion}

Oral cancer is a public health problem in many countries and ranks among the ten most frequently diagnosed cancers all over the world, according to the 2018 GLOBOCAN report [31]. Since the identification of the TP53 codon 72 polymorphism as potential risk factor for cancers, numerous studies have been devoted to explore the genetic effect of this polymorphism and its association with oral cancer risk. Some studies claimed that this SNP is a risk factor for oral cancer while other studies detected no effect in oral carcinogenesis, showing clear discrepancy between results across the world. The different patterns noticed in allelic distribution and genotypic frequencies of this polymorphism may be due to variations in methodological approaches, sample size, laboratory performance, DNA quality and source, variation in ethnic background or environmental exposures of study populations $[16,32,33]$.

We have performed an ethnicity-stratified meta-analysis to check the association between TP53 codon 72 polymorphism and OSCC risk. Overall, 16 publications with 9024 subjects (4288 cases and 4736 controls) were included in this study. Comparison of Arg allele frequencies between cases and controls was statistically significant only in Asian subgroup. Also, we've found significant associations between the TP53 Arg72Pro polymorphism and OSCC risk for four contrasts models in Asians. Hence, this polymorphism was not significantly associated with any increased or a decreased risk of OSCC in Africans and Caucasians.

Several stratified meta-analysis based on TP53 Arg72Pro polymorphism and different types of cancer have been performed to date, but evidence of the implication of this polymorphism remains unclear.

A meta-analysis by Koushik et al. in 2004 on cervical cancer risk and TP53 Arg72Pro polymorphism revealed that the homozygote Arg/Arg genotype was significantly associated with an increased susceptibility to cervical cancer [34]. Also, a meta-analysis in Iran about breast cancer found that the risk of developing breast cancer is 1.58 higher in Iranian women with genotype Arg/ $\operatorname{Arg}(95 \% \mathrm{Cl}: 1.01$ to 2.45$)$ [35].

On the contrary, Zhuo et al. in 2009 demonstrated that the Arg allele was associated with a decreased risk of nasopharyngeal cancer [36]. Another meta-analysis on nasopharyngeal cancer published in 2016 has meanwhile evidenced that the TP53 codon 72 polymorphism could be as a risk factor [37].

Concerning oral cancer risk, a meta-analysis pooling nine studies published until May 2009 (1990 cases and 2074 controls) showed no association; likewise, another one published in 2013 with seventeen studies stratified according to ethnicity confirmed no significant association in Asians, Caucasians and mixed populations $[22,38]$. To our knowledge, our meta-analysis is the first to investigate the association of TP53 codon 72 polymorphism with OSCC risk in the three ethnic populations, Caucasians, Asians and Africans and highlighted that Arg allele of TP53 codon 72 could be considered as a risk factor for OSCC in Asian population.

\section{Conclusion}

The present meta-analysis shows that Arginine allele of TP53 codon 72 polymorphism was significantly associated with OSCC risk in Asian population whereas any significant link was observed in Africans and Caucasians. Our study also confirmed that genotypes distribution of the TP53 codon 72 polymorphism may be dependent on ethnicity and geographic latitude. Further extensive studies using functional approaches are then required to confirm the real influence of Arg72Pro polymorphism on OSCC risk.

\section{Acknowledgements}

The authors thank all colleagues who participated in this work, particularly Mr. Thierno Dieng (Head of Obstetrics and Gynecological Clinic, Aristide Le Dantec Hospital, Dakar-Senegal) and Mr. Cheikh Loucoubar (Head of the Epidemiology Unit, Clinical Research and Data Science Department of Institut Pasteur de Dakar, Senegal) for their invaluable contributions during statistical analysis.

\section{Conflict of Interest}

No potential conflicts of interest were disclosed.

\section{References}

1. Perrone, Federica, Luigi Mariani, Elisa Pastore and Marta Orsenigo, et al. "p53 Codon 72 Polymorphisms in Human Papillomavirus-Negative and Human Papillomavirus-Positive Squamous Cell Carcinomas of the Oropharynx". Cancer 109(2007): 2461-2465.

2. Zushi, Yusuke, Mako Narisawa-Saito, Kazuma Noguchi and Yuki Yoshimatsu, et al. "An in vitro Multistep Carcinogenesis Model for Both HPV-Positive and -Negative Human Oral Squamous Cell Carcinomas". Am J Cancer Res 1(2011): 869-881.

3. Mojtahedi, Zahra, Seyed Basir Hashemi, Bijan Khademi and Morteza Karimi, et al. (2010) "p53 codon 72 Polymorphism Association with Head and Neck Squamous Cell Carcinoma". Braz J Otorhinolaryngol 76(2010): 316-320.

4. Shen, Hongbing, Yuxin Zheng, Erich M Sturgis and Margaret R. Spitz, et al. "P53 codon 72 Polymorphism and Risk of Squamous Cell Carcinoma of the Head And Neck: A Case-Control Study". Cancer Lett 183(2002): 123-130.

5. Yang, W, Zhang $Y$, Tian $X$ and Ning $T$, et al. "p53 Codon 72 Polymorphism and the Risk of Esophageal Squamous Cell Carcinoma". Mol Carcinog 47(2008): 100-104.

6. Patel, KR, BN Vajaria, RD Singh and R Begum, et al. "Clinical Implications of p53 Alterations in Oral Cancer Progression: A Review From India". Exp Oncol 40(2018): 10-18.

7. Kietthubthew, Suparp, Hutcha Sriplung, William W Au and Takafumi Ishida. "The p53 Codon 72 Polymorphism and Risk of Oral Cancer in Southern Thailand". Asian Pac J Cancer Prev 4(2003): 209-214.

8. Yu, Hongping, Yu-jing Huang, Zhensheng Liu and Li-E. Wang, et al. "Effects of MDM2 Promoter Polymorphisms and p53 Codon 72 Polymorphism on Risk and Age at Onset of Squamous Cell Carcinoma of the Head and Neck". Mol Carcinog 50(2011): 697-706.

9. Ji, Xuemei, Ana S Neumann, Erich M Sturgis and Karen Adler-Storthz, et al. "p53 codon 72 polymorphism associated with risk of human papillomavirus-associated squamous cell carcinoma of the oropharynx in never-smokers". Carcinogenesis 29(2008): 875-879.

10. Duffy, Michael J, Naoise C Synnott, Patricia M McGowan and John Crown, et al. "p53 as a Target for the Treatment of Cancer". Cancer Treat Rev 40(2014): 1153-1160.

11. Castellanos, Mario R and Quintin Pan. "Novel p53 Therapies for Head and Neck Cancer". World J Otorhinolaryngol Head Neck Surg 2(2016): 68-75.

12. Scheckenbach, Kathrin, Oliver Lieven, Karl Götte and Ulrike Bockmühl, et al. "p53 Codon 72 Polymorphic Variants, Loss of Allele-Specific Transcription, and Human Papilloma Virus 16 and/or 18 E6 Messenger 
RNA Expression in Squamous Cell Carcinomas of the Head and Neck". Cancer Epidemiol Biomarkers Prev 13(2004): 1805-1809.

13. Twu, Chih-Wen, Rong-San Jiang, Chih-Hung Shu and Jin-Ching Lin. "Association of p53 codon 72 polymorphism with risk of hypopharyngeal squamous cell carcinoma in Taiwan". J Formos Med Assoc 105(2006): 99-104.

14. Sourvinos, G, E Rizos and DA Spandidos. "p53 Codon 72 Polymorphism is linked to the Development and not the Progression of Benign and Malignant Laryngeal Tumours". Oral Oncol 37(2001): 572-578.

15. Chen, Xingming, Erich M Sturgis, Adel K El-Naggar and Qingyi Wei. "Combined Effects of the p53 Codon 72 and p73 G4C14-to-A4T14 Polymorphisms on the Risk of HPV16-Associated Oral Cancer in NeverSmokers". Carcinogenesis 29(2008): 2120-2125.

16. Hou, Jun, Ying Gu, Wei Hou and Song Wu, et al. "P53 Codon 72 Polymorphism, Human Papillomavirus Infection, and their Interaction to Oral Carcinoma Susceptibility". BMC Genet 16(2015): 72.

17. Brant, Ommo, Markus Hoffmann, Anthony Kanappilly and Tibor Goeroegh, et al. "P53 Codon 72 Polymorph. "P53 Codon 72 Polymorphism in Squamous Cell Carcinoma of the Head and Neck Region". Anticancer Res 27(2007): 3301-3305.

18. Beckman, G, R Birgander, A Själander and N Saha, et al. "Is p53 Polymorphism Maintained by Natural Selection? " Hum Hered 44(1994): 266-270.

19. Fuentes, M, I Pulgar, C Gallo and MC Bortolini, et al. "Gene Geography of Chile: Regional Distribution of American, European and African Genetic Contributions". Rev Med Chil 142(2014): 281-289.

20. Kashima, Taeko, Kumiko Makino, Augustinua Soemantri and Takafumi Ishida. "TP53 Codon 72 Polymorphism in 12 Populations of Insular Southeast Asia and Oceania". J Hum Genet 52(2007): 694-697.

21. Själander, A, R Birgander, N Saha and L Beckman, et al. "p53 Polymorphisms and Haplotypes Show Distinct Differences Between Major Ethnic Groups". Hum Hered 46(1996): 41-48.

22. Jiang, Ning, Jie Pan, Lei Wang and Yin-Zhong Duan. "No Significant Association between p53 Codon 72 Arg/Pro Polymorphism And Risk Of Oral Cancer". Tumour Biol 34(2013): 587-596.

23. Liu, Ting, Zeyuan Lei, ZhengYing Pan and Yu Chen, et al. "Genetic Association between p53 Codon 72 Polymorphism and Risk of Cutaneous Squamous Cell Carcinoma". Tumour Biol 35(2014): 3899-3903.

24. http://www.aly-abbara.com/utilitaires/statistiques/khi_carre_rr_odds_ ratio_ic.html.

25. Ba SA (2014) Study of the Polymorphism of Codon 72 of the p53 Gene as a Risk Factor in Cancers of the Oral Cavity in Senegal. State Doctorate Thesis in Pharmacy, Cheikh Anta Diop University of Dakar, Senegal.

26. Hamel N, Black MJ, Ghadirian P and Foulkes WD. "No Association between P53 Codon 72 Polymorphism and Risk of Squamous Cell Carcinoma of the Head and Neck". Br J Cancer 82(2000): 757-759.

27. Lin, Ying-Chu, Hsin-I Huang, Li-Hsuan Wang and Chi-Cheng Tsai, et al.
"Polymorphisms of COX-2 -765G >C and p53 Codon 72 and Risks of Oral Squamous Cell Carcinoma in a Taiwan Population". Oral Oncol 44(2008): 798-804.

28. Lu, Jiachun, Li E Wang, Ping Xiong and Erich M Sturgis, et al. "172G>T Variant in the $5^{\prime}$ Untranslated Region of DNA Repair Gene RAD51 Reduces Risk of Squamous Cell Carcinoma of the Head and Neck and Interacts with a P53 Codon 72 Variant". Carcinogenesis 28(2007): 988994.

29. Sina, Mahmud, Mehrdad Pedram, Morteza Ghojazadeh and Ahmad Kochaki, et al. "P53 Gene Codon 72 Polymorphism in Patients with Oral Squamous Cell Carcinoma in the Population of Northern Iran". Med Oral Patol Oral Cir Bucal 19(2014): e550-555.

30. Tu, Hsi-Feng, Hong-Wen Chen, Shou-Yen Kao and Shu-Chun Lin, et al. "MDM2 SNP 309 and p53 Codon 72 Polymorphisms are Associated with the Outcome of Oral Carcinoma Patients Receiving Postoperative Irradiation". Radiother Oncol 87(2008): 243-252.

31. Bray, F, J Ferlay, I Soerjomataram and RL Siegel, et al. "Global Cancer Statistics 2018: GLOBOCAN Estimates of Incidence and Mortality Worldwide for 36 Cancers in 185 countries". CA Cancer J Clin 68(2018): 394-424.

32. Lin, Ying-Mei, Jun Shao, Xiao-Hong Yin and CaiCai Huang, et al. "Meta-Analysis Results on the Association Between TP53 Codon 72 Polymorphism with the Susceptibility to Oral Cancer". Front Physiol 9 (2018): 1014.

33. Assoumou, Samira Zoa, Anicet Luc M Boumba, Angelique NdjoyiMbiguino and Abdelkrim Khattabi, et al. "The Preliminary Study of p53 Codon 72 Polymorphism and Risk of Cervical Carcinoma in Gabonese Women". Med Oncol 32(2015): 281.

34. Koushik, Anita, Robert W Platt and Eduardo L Franco. "p53 Codon 72 Polymorphism and cervical neoplasia: A Meta-Analysis Review". Cancer Epidemiol Biomarkers Prev 13(2004): 11-22.

35. Soleimani, Abozar, Yousef Rahmani, Negin Farshchian and Ali Delpisheh, et al. (2016) "The Evaluation of p53 Polymorphism at Codon 72 and Association with Breast Cancer in Iran: A Systematic Review and Metaanalysis". J Cancer Prev 21(2016): 288-293.

36. Zhuo, Xian-Lu, Lei Cai, Zhao-Lan Xiang and Wen-Lei Zhuo, et al. "TP53 Codon 72 Polymorphism Contributes to Nasopharyngeal Cancer Susceptibility: A Meta-Analysis". Arch Med Res 40(2009): 299-305.

37. Sahu, Sushil Kumar, Sudipta Chakrabarti, SD Roy and N Baishya, et al. "Association of p53 Codon72 Arg>Pro Polymorphism with Susceptibility to Nasopharyngeal Carcinoma: Evidence from a Case-Control Study and Meta-Analysis". Oncogenesis 5 (2016): e225.

38. Zhuo, Xian-Lu, Qi Li, Yan Zhou and Lei Cai, et al. (2009) "Study on TP53 Codon 72 Polymorphisms with Oral Carcinoma Susceptibility". Arch Med Res 40(2009): 625-634.

How to cite this article: Diaga, Sarr Pierre, Seydi B.A. Abdoul, Silly T and D'Jean Pascal Demba, et al. "Association of the TP53 Arg72Pro Polymorphism with Oral Squamous Cell Carcinoma: A Meta-Analysis." J Mol Genet Med 14 (2020): 455 doi: 10.37421/jmgm.2020.14.455 